\title{
WHAT SHALL WE THINK OF CREEDS?
}

\section{Professor Edward B. Poluard, D.D., Chester, Pa.}

Religion, which has its roots deep in the very nature of men, is summed up in experience and expression. Religion expresses itself in three ways: as cult, as creed, and as conduct. The savage has little or no theology. His creed is shadowy, lying chiefly in the subliminal consciousness. He does not explain why he performs this or that rite, he has inherited it. Among primitive peoples ceremonies bulk large. With them, cult is far more important than ereed, and has little, if any, relation to conduct. True, savages have their beliefs, more or less vague, concerning the spirit world, but no creedal statements. Creeds are born when men begin to intellectualize their religious experiences, or when individualism asserts itself against the established social mind. So, parties begin ito be formed; and at length the social feeling reasserts itself ; and then comes the feeling that statements are necessary in order to include those to be regarded as regular, or orthodox, and to exclude the irregular, or heterodox. It is inevitable that men should think upon spiritual phenomena, should try to explain and classify their religious experiences. Hence there comes the creedal stage of development.

In the case of the Christian religion, this stage was reached when Hellenism conquered the Christian world.

There were three distinct types of life at work in the development of the early Christian life and institutions. The first, the Hebrew mind, being characteristically intuitive and discursive, made no demand for a succinct, logical statement of doctrine. The Hebrews had no eye for the minute anatomy of thought. They thought in terms of life; their religious constitution, the Old Testament, was like the British Constitution, a sort of common law built up on cases, judgments of real life. Unfortu- 
nately, however, this type of mind too soon disappeared from the Christian church; for Christian success among the Jews was all too short-lived. Its representatives turned to the Gentiles. Here the Greek type of mind was met and conquered; though in turn the Greek mind conquered Christian thinking, as it had, in fact, conquered the entire Roman world. Now, the Greek had a genius for harmony. In the realm of sound, this genius gave the world poetry and music; in the realm of form and color it produced painting, sculpture, architecture. In the sphere of thought, this same genius produced philosophy, demanding systematic, harmonious thinking. Hence formal statements of Christian doctrine were required. This demand was reinforced by the Roman type of mind, which, though its learning had been captured by the Greek culture, in practical administration was autonomous, and as imperial in its thinking as ever. The Roman imperialism demanded conformity. The pronouncements from the cathedra, or seat of power, were to be accepted without delay and without addition or substraction; therefore arose creeds, that is credenda. In other words, the Greek influence would not have been hurtful had it not been conquered by a people whose key-note was unity and uniformity. The Reformation was, essentially, a revolt against the Roman imperialism which had shown itself in the crushing of individual thought, and reducing the world to a dead religious level. Both the material principle of the Reformation--justification, by direct personal faith in Christ, apart from the intervention of church or symbol; and the formal principle- the Bible, and the Bible only the norm of faith and practice-were distinctly inimical to the authority of creedal statements of religious truths. And yet, at once, reform creeds began to be born in broods. Scholasticism, revelling with delight in fine-spun distinctions, was just spoiling for an opportunity to show its skill in elaborate creed-making. And some modern Christians are still living under the 
shadow of those days of creedal fertility and upgrowth. There are several reasons why the authoritative creed has been condemned before the bar of this age.

First, We have discerned that religion does not have its seat in the intellect. Religion may make men think, but thinking does not make men religious. Religion is reasonable but the reason is not religious. Since Schleiermacher wrote his Reden über die Religion, it has become increasingly difficult to confuse religion with interpretations of it. At one time, to throw religion into the realm of feeling was to condemn it with intellectual men. This is no longer true. The feelings have come to their own. Hegelianism, which places religion in the realm of the intellect, is hopelessly bankrupt. Modern psychological studies have accentuated the conviction that religion lies deep in the subconscious feeling, in the unreasoning intuitions, which are the inheritance of the race. And just as no one confounds botany with the flower, nor astronomy with the twinkling star, so assent to theological statements can never again be regarded as a religious act. In truth, it would seem that one of the best ways to squeeze religion out of anything is to reduce it to thought categories. As has been said:

"Philosophers are lined with eyes within, And being so, the sage unmakes the man. In love, he cannot therefore cease to trade; Scarce the first blush has overspread his cheek, $\mathrm{He}$ feels it, introverts his learned eye,

To catch the unconscious heart in the very act.

His mother died-the only friend he had-

Some tears escaped, but his philosophy

Couched like a cat, sat watching close behind And throttled all his passion."

Stcond, We have come to realize better than formerly how creeds are made. Creeds have very generally arisen 
out of party strife. They are constructed when some truth is regarded in danger, and some heretic needs to be shut out or shut up! There were two principal periods of creed-making. First, the period when the nature of the person of Christ was the subject of hot debate in the third and fourth centuries-an era which gave birth to the Nicene and the Athanasian creeds; and second, the period following the Reformation when Protestantism was in deadly combat with Rome. The polemic character is deep-marked in the great historic creeds. Now, nothing religiously normal can be born amid the din and throes of battle. False emphasis is inevitable. You only need to be reminded that the Westminster confession, though elaborate enough upon predestination, has only incidental reference to the Holy Spirit and is altogether silent upon the Fatherhood of God, and says nothing whatever about the Kingdom of God. The New Hampshire confession contains eighteen articles but has none on God's fatherhood, on the Holy Spirit, the kingdom of God, nor on the supremacy of love in the Christian life.

Creeds have been compared to canned goods. The making of them is an effort to preserve the truth; as though truth can ever spoil. A creed therefore is at best, a sort of embalmed religion, and as with much of the canned meat we get, one has only to know how it is made to reject it. If the creed be born in polemics it is lopsided; dealing fully with the disputed, and leaving the undisputed, however vital, untouched., Should it, perchance, have its birth, as some creeds have, in an effort to reconcile parties, that they may stand upon a common platform, the result is compromise, and hence it cannot be really representative of any. Made by all it is believed by none of its promulgators. So we have the absurdity that all subsequent believers are enjoined to believe exactly what nobody believed entirely. Thus some creeds, like political platforms, become only make-shifts, dealing unmistakably with those things about which no one cares, 
but uncertainly, equivocally upon those concerning which there is disagreement. In such cases, it turns out that the creed is of chief interest as representing not what its makers hold, but that which they are willing to surrender, the theological give-aways, or refuse of religious thinking. Controversy with those without, and compromise with those within are surely not conducive to healthy statements of religious faith. The fact is, those things in religion that are really worth defining defy definition. No statement concerning God and His attributes can possibly be adequate for the truly religious soul. There is profound wisdom in the report of Moses' experience at the burning bush: "Who shall I say", "Tell them I $A M$ hath sent thee." "To label God, is to lose Him.

The history of creed-making further discounts the authoritative creed, in that statements that were not designed to be compelling upon the consciences of all, gradually become of binding force; and, indeed, identical with truth itself. So the creeds, credita, become creeds credenda. As Harnack remarks concerning the making of a creed: "Its forms at once stiffen; in the very process of stiffening they receive for the first time their real significance, and new forms are added. Not only do they acquire the value of laws and regulations, but they come to be insensibly regarded as though they contained within them the very substance of religion, nay, as though they were themselves that substance." (What is Religion, p. 212.) And, just as the brazen serpent, lifted up to serve a vital purpose in the wilderness, but becoming later an object of worship, was indignantly dubbed a scrap of brass, fit only for rubbish, so creeds, however piously originated, tend to become objects of authoritative reverence and are then fit only for being ground to powder, or put again into the melting-pot. The Jews came to identify religion with an affair on Mount Moriah, so God left not one stone upon another, that religion might come again to its birth-right of freedom. It is 
Rome's most blighting of errors, still lingering among some Protestants, which identifies forms of truth with truth itself, the church with the kingdom, creed with Christianity.

A third reason why this age cannot think well of creeds, lies in the growth of the democratic spirit which makes it no longer possible for confessions to hold authoritative influence over men of to-day. Neither the richest scholar nor the ripest saint, nor any collection of them, can again hope to dominate the world's thinking as formerly. No matter who wrote the creed which bears the name of Athanasius, the influence of no single name can ever again be so compelling. I feel sure also that in case of people so innocent of this creedal heresy as Baptists, it will never be possible for one like J. Newton Brown, to draw up an accepted Baptist confession. Both scholarship and sainthood are now too democratic for this.

A fourth reason why the anthoritative creed is doomed, is that since evolutionary hypothesis came to be applied to things spiritual, taking the dictum of Heraclitus as its own návra $\grave{\rho}^{\prime} \iota$ "everything flows," the age finds it impossible to believe that any one era can make a statement which shall satisfy the ever-expanding spirit, and intelligence of the next age-as impossible as it would be for any living organism to produce an egg in a shell so large, so perfect, and so strong as to furnish satisfactory home for the matured life of the creature. Such an attempted dwelling would be first a prison, then a tomb.

It is to be remembered, further, that we have gradually come to the day when it is possible for those who believe differently to work harmoniously in a common fellowship toward common practical ends. The growth of Christianity makes the need of uniformity through the pressure of authoritative creeds no longer felt. Henry VIII forced through Parliament an act known as a law "for the abolition of diversity of opinion!" This to-day 
would be neither possible nor necessary. The greatest schism that ever occurred in the Christian Church, unless it be that of the Protestant Reformation, was that of split of East from West, Greek from Roman Church. That there should ever occur such a division over the addition of the word filioque to the article on the procession of the Spirit, is unthinkable.

The various denominations have not been altogether blind to the age-spirit which demands at least that creeds be no longer dead things. The expedients employed to meet its demands are most instructive. The Roman Catholic Church, through the Vatican Council of 1870 , declared the Pope when he speaks ex cathedra to be infallible in all matters pertaining to faith and morals-thus, giving, as it were, a certain living continuity to the Church's authority, in the perpetual person of the Pope. So, there is a living exponent of truth, authority incarnate; and hence able to speak as changing conditions may require. This is a most comfortable substitute for a hard and fast creedal system for those who can accept the Vatican doctrine of papal infallibility.

A second expedient for adapting a creedal idea of religion to the modern conception of an ever-expanding knowledge of divine truth, is discerned in certain religious bodies, such as the Church of England and its American sister the Protestant Episcopal Church. Professor A. V. G. Allen; in his instructive volume, "Freedom in the Church", represents this attitude, when he advocates what may be called a policy of freedom of construction. That is, keep the historic creed just as it is, but do not feel compelled to get out of it what the fathers read there, or what the founders meant when they drew up its articles. "Maker of Heaven and Earth" should of course not be interpreted as referring to creation in the old traditional sense which modern science and philosophy no longer sanction. "He descended into hell" and "He ascended into Heaven" are no longer to be understood in the early 
sense of those words, but in a more spiritual and mystical sense. "Born of the Virgin Mary" is no longer to be read "Born of the Virgin Mary, so much as "Born of the virgin Mary"'; that is, that the emphasis is on the humanity of the new born Saviour, rather than upon the virginity of the mother. In short, that when a priest takes the solemn obligation "to administer the Doctrine and the Sacraments and the Discipline of Christ as the Lord hath commanded and as the church hath received the same, according to the commandments of God," he is not to understand that he is under obligation to interpret the creed according to the opinions of the past (for these are not by any means uniform), but in accordance with the new light which the new age may throw upon the tenets of the Church. In this way, by a sort of mental reserve, or an ecclesiastical fiction, a young priest need not hesitate to give complete assent to every article of the historic creed. He can interpret it to suit himself! In this way, not only. will freedom be secured within the Church and the disgrace of heresy trials be averted; but the Church can always put itself abreast with the best light of every age, and nullify the evils of a hard and fast written creedal authority. That is, why may we not apply the "rule of reason" to things theologic? Or may we not adopt the view of Professor Sanday in his "Christologies Ancient and Modern," in which he says that when he repeats a creed he always repeats it, not as an individual but as a member of a church, or as Theodore T. Munger used to declare, he said the Apostles' Creed just as be would sing an oratorio, as an act of worship, and not necessarily assenting intellectually to any particular article in it, or any definition of it!

A third method of dealing with the problem is an occasional revision of the creed, or by use of footnotes to reinterpret the outgrown portions. After many years of agitation, argument and much heart-burning-though no 
heretics were burned at the physical stake-the Presbyterian Church tried moderately this expedient for conforming the policy of a set authoritative creed to presentday light and the modern faith. A large number of Presbyterians were, however, more favorable to the method already referred to, of freedom of construction; while others thought that to keep an article which nobody believed, except after a mental contortion, smacked of dishonesty and tended to foster hypocrisy among the ministers who at their ordination must pledge themselves to teach the Westminster Confession and other Standards of the Church, parts of which they, with many others, had ceased to believe. But the revision policy has proved to be so difficult as to be almost prohibitory; consequently the history of creedal changes has been much like the history of the Constitution of the United States-the interpretations of Supreme Court justices and the logic of events have done more for its expansion and development than have actual amendments. And it is interesting to note that in a late Encyclical letter of the former Pope, among the heresies against which he warned the faithful is this: "The principal articles of the Apostles' Creed had not the same significance to the primitive Christians as they have to the Christians of the present time."

An instructive example may also be cited from a recent bit of church history, in the revision of article 36 in the Confessio Belgica (of the Reformed Church of Holland). The article in question stated that "Magistrates are in duty bound to prohibit and extirpate all idolatry and false religion, and to overthrow the Kingdom of Anti-Christ." Such an article was placed in all the Reformed creeds, having its roots back in the writings of the Fathers, who based their arguments upon a few passages from the Old Testament and quotations from the Justinian Code; especially in Augustine, with his rigid impelle.intrare. Calvin passed this on, in first-rate running order, not only in his treatise on 
Servetus but in his Institutes, (Bk. V, Ch. 20, Sec. 53). A few years ago, the Synod of the Reformed Church of Holland, after much discussion, and insistence that the section in question be revised, came to the conclusion that there was not sufficient agreement as to the way the said article ought to be changed, to revise it suocessfully; that to act upon the proposal to add footnotes explaining that the article does not mean what it says and probably never did (!) would be untrue to history-and so they simply dropped out the words upon which the gravamen rested, though with a very considerable minority vote.

All this means, that modern Protestant Christianity is wrestling with the problem of reconciling two unreconcilable ideas, how to maintain a written authoritative creed and yet let in the living light of God's ever expanding Spirit, and of man's ever-widening experience. That is, how to maintain in force an inheritance from Rome, which Rome has herself, through the declaration of papal infallibility, practically abandoned.

We do not here maintain that the ereeds are wholly bad. They have served some good purposes. They have had a certain educative value; and have at times made for solidarity and co-operation. They have tended to counteract an exaggerated subjectivity in religion. Their history gives the history of the struggle of the race to think religion-to conquer the thought realm of religion and at the same time to advance in solid phalanx against a common foe.

There are perhaps evidences in the New Testament of incipient confessions, as in 1 Timothy $3: 16$. "He who was manifested in the flesh, justified in the spirit, seen of angels, preached among the nations, believed on in the world, received up in glory.",

So also in Hebrews 6:1-3. "Leaving the first principles, etc."

Creeds, however, once a unifying force, now rather become divisive. Designed to be educative they become 
reactionary, producing religious stand-patism, and sometimes spiritual retrogression.

What then is the solution of the problem? The mental imperative is for orderly thinking; the common sense practical spirit of the age demands that a man shall believe something; shall have convictions, not nebulous guesses at truth with which only the jelly-fish type of religious character could be satisfied. And on the other hand the progressive spirit of the age will not tolerate the idea that any formula of doctrine can be so constructed as to be entirely satisfactory even for today, and still less, binding upon tomorrow. This time-spirit does not say, "Make no more creeds." Much less does it enjoin : "Believe nothing." What saith it? Continue to make creeds. Make more and more of them. Let Protestantism have its perfect work, and let every man patiently work out his belief with fear and trembling, and with the guidance of all light that he can get, both human and divine. Let it be serious and earnest creedmaking, an honest effort to express the truth as it is seen. But surely let no one think of such a statement as final or as authoritative, but simply as a relative guide to the honest seeker for the truth, a statement of didactic value, but not of binding force. Make creeds often, but be sure to throw the old aside when a better has been formulated; for even the less imperial churches come after a while to glorify their creedal statements into something like sacred value; punishing the non-conformist, not by excommunication, nor by torture at the stake, but by a merciless species of roasting through public opinion, kindled by religious newspaper pulp, which is the modern democratic auto $d a$ fe. Creeds have been rightly called the precipitates of the religious consciousness of mighty men and times. Sabatier has well expressed the thought in these words: "If the life of a church be compared to that of a plant, doctrine holds in it the place of the seed. Like the seed, doctrine is the last to be formed; it crowns 
and closes the annual cycle of vegetation; but it is necessary that it should form and ripen; for it carries within it the power of life and the germ of a new development. A church without dogmas would be a sterile plant. "Except a grain of wheat fall into the ground and die, etc." To be fruitful, dogma must be decomposed-that is to say, it must mix itself unceasingly with the evolution of human thought and die in it; it is the condition of perpetual resurrection. Then creeds will not fall nnder the witty condemnation of Forsyth, inveighing against unvitalized theology as "canned goods gone stale."

When creeds die in the larger life of the people they are at their very best. As Shelly makes the cloud say:

"I silently laugh at my own cenotaph

And out of the caverns of rain,

Like a child from the womb,

Like a ghost from the tomb,

I arise and upbuild it again."

Men do not refuse to give clothing to their children because they will only outgrow them next year. A gentleman does not decline to wash his face because it will surely need washing again tomorrow. Such creeds as those of which I speak are way-marks along the road of Christian progress. On the contrary, authoritative creeds are steps in religious degeneracy. They mark "the place where men stop thinking." This must always mean decay. Austin Phelps quoting Orestes Bronson gives clearly the steps in this process of decay: "The Fathers studied and expounded the scriptures-and they were strong men, heroes of their times. The medieval doctors studied, systematized, epitomized the Fathers; and they, though still great, fell below those who were formed by the study of the scriptures themselves. The theologians followed, and gave compendiums of the doctors, and fell still lower. Modern professors content 
themselves with giving compendiums of the compendiums given by the theologians and have fallen as low as possible without falling into nothing and disappearing in the inane."

The form in which our Scriptures have come to us is the only form that does not need reconstruction from age to age. This is one reason why it has so long held its place as a norm of belief. The Bible speaks in terms of life, rather than of formulæ. It is not so much logical as biological. Life can never be confined by logic; it transcends all diagrams and tables. It is the only sort of creed an age like ours can continue to accept. The Bible's method of presenting any doctrine shows itself to be infinitely superior to any formulated statement made for the purpose of embodying that doctrine. The Bible statement is vital, germinal in character and method; while a formula is a crystal, which may be ever so symmetrical, or even mathematically exact, and yet is devoid of life, and hence lacking in the capacity of adaptation and of growth. The Bible is good for all ages; a formulated creed is good for only one age. The Bible may be reinterpreted as new light is thrown upon its teachings. Reinterpretation of a creed is like reinterpreting a brick house. A poem may be reinterpreted, but not an algebraic formula. The reason why the socalled "Apostles' creed" is still of widespread use, is because it deals with a few simple facts, and is silent as to their interpretation.

If men must have a creed other than the Scriptures, then let the creed not attempt to linger in the intellectual realm alone. The intuitions of men are more apt to be correct than the intellect. The feelings, though they fluctuate as the needle, are more certain to point to the pole, than is the reason to arrive, after its gropings from inference to inference. Let the creed be more poetic in character; let it use wings of a bird and not the exactitude of the measuring worm. 
Creeds which move alone in the realm of the reason must always be divisive. In the thought Kingdom men differ; in the Kingdom of the heart they bow submissively before the same Lord. It is for this reason that we always find that when religion rises into its highest values, it at once drops the terminology of the schools, and takes the wings of song. Then all stand with uncovered head and listen, and all join in the music of the upper air. The Christian world comes together in the ohoir not in the Conference and the Synod.

The twentieth century creed must also take account of conduct. It must contain articles like this: "I believe in the holy Christian character, in the consecration of the saints, in catholic honesty and justice, in kindness and mercy and love. I believe in both the worship and work of the church and the spread of the gospel among all peoples." The cult is what religion makes men do socially when they worship their God. Creed is what religion causes men to think when they interpret their experiences. Conduct is what a man's religion causes him to do toward or for his fellowman. The prophet Micah wrote the best short article for this kind of creed that is extant. "What doth Jehovah require of thee, but to do justly, and to love mercy, and to walk humbly with thy God." Micah 6:8. Prof. Hatch calls attention to the fact that the desire in the early centuries to hasten the coming of the kingdom, by taking the world into the church, caused practical life to be neglected, and so, "Side by side with the diminution of strictness of moral tests of admission was a growth of the importance of the intellectual elements." The assent to the creed became a sort of gangplank upon which both clean and unclean beasts went into the ark of safety.

That is to say, the modern creed must take into consideration the emotional and the volitional as well as the intellectual elements of the religious life. In other words, a twentieth century creed should be individual, rather 
than collective; voluntary, rather than compulsory; educative, rather than authoritative; emotive, rather than initellectual; experimental, rather than speculative; practical, rather than metaphysical; fluid and not fixed.

But would not such a creed be a very loose sort of a pronouncement? Assuredly; but it is the tight confession that has done most mischief, fostering division and scepticism, rather than faith and unity. We are reminded of the remark of Jacobi, "I believe by my faith; by my reason, I am a heathen." It is not intellection that brings men to God, nor will reason keep them there.

Must it still be asked, how is the purity of the faith to be safeguarded without authoritative standards? This is the age-long distrust of God and truth. Truth is best insured by freedom to think, to believe and to speak. Certainly creedis have failed to insure religious purity. Christian experience is the best safeguard of correct religious thinking; and bad men destroy faith and rend the church quite as much as heretic ever did. I hold no brief for the heretic, but life and not creeds safeguards religion.

We are forever building upon what the fathers have thought and done. This is right; but we must build. Truth bids us not stay, but go. What "first were guesised as points we now know stars." We advance from "falsehood like truth to truth itself.'" So we must

"Presis on, and prove the pilgrim hope of youth That creeds are mile-stones on the road to truth." 